\title{
Primórdios da psiquiatria no Brasil
}

\author{
The origins of psychiatry in Brazil
}

\author{
Othon Bastos* \\ * Professor titular de Psiquiatria, Universidade Federal de Pernambuco (UFPE) e Universidade Estadual \\ de Pernambuco, Recife, PE. Ex-Presidente, Associação Brasileira de Psiquiatria (1992/1995). E-mail: \\ othon@br.inter.net
}

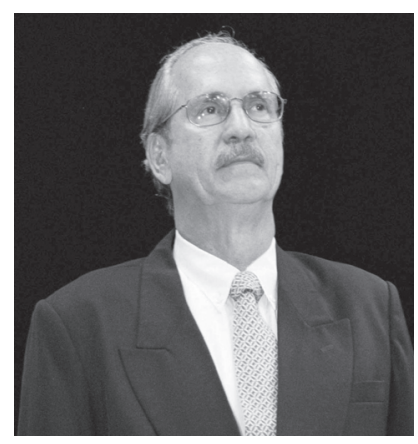

Costumo afirmar, em tom jocoso, que a história oficial da psiquiatria no Brasil teve início com a chegada da família real portuguesa ao Rio de Janeiro, em 1808, trazendo a bordo, "engaiolada", a rainha D. Maria I. Sua Alteza havia sido considerada insana e afastada de suas funções pelo médico da corte, o pernambucano José Correia Picanço, primeiro Barão de Goiana, fundador dos cursos médicos no país.

Nessa época, os doentes mentais costumavam perambular pelas ruas das principais cidades e vilas brasileiras, servindo de galhofa aos habitantes, ou então viviam segregados em solitárias ou quartosfortes nos fundos dos quintais das famílias mais abastadas. Esse fato despertava críticas e reclamações de setores mais esclarecidos da população.

As Santas Casas de Misericórdia das cidades maiores passaram, então, a recolher, ao longo do primeiro reinado e das regências, os insanos mentais em seus hospitais. Os andares superiores eram destinados aos pacientes clínicos e cirúrgicos, enquanto que os "loucos" eram jogados nos porões infectos dos estabelecimentos, habitualmente situados abaixo dos pacientes portadores de cólera. Os mais agitados eram presos ao tronco e espancados pelos guardas. Há registros dessas ocorrências na Santa Casa de S. João Del Rei, em 1817, primeira referência histórica; no Hospital de São Cristóvão, na Bahia; no Hospital de São Pedro de Alcântara, em Recife; e na Santa Casa de Misericórdia do Rio de Janeiro, nas primeiras décadas do século XIX.

Aumentou, porém, o clamor contra os maus-tratos sofridos pelos doentes mentais, que atingiu seu clímax após a criação da Sociedade de Medicina do Rio de Janeiro. A partir de 1830, os médicos J. M. da Cruz Jobim, J. F. Sigaud, L. V. De Simoni e Antônio Luiz da Silva Peixoto, autor da primeira Tese sobre Psiquiatria no Brasil (1837), passaram a atacar intensamente a situação. Os protestos foram ouvidos pelo Ministro do Império e Provedor da Santa Casa, José Clemente Pereira, que decidiu, através de recursos públicos e doações de particulares, erigir o Hospício de Pedro II, na Praia Vermelha, construção iniciada em 1841 e inaugurada suntuosamente em dezembro de 1852, comemorando a maioridade antecipada do jovem monarca. "O mais belo prédio, em estilo neoclássico da época, da América do Sul". O professor Leme Lopes, a respeito do Hospício Nacional de Alienados, denominação recebida após a Proclamação da República, e futura sede da Reitoria da antiga Universidade do Brasil, nos anos 40 do século passado, lembrava a prodigalidade de estátuas existentes em seu salão nobre e ironicamente dizia que apenas as da caridade e da justiça permaneceram fora da edificação.

O Hospício Pedro II tinha essencialmente as finalidades custodial e asilar, buscando isolar os doentes mentais, alienando-os do convívio social. A instituição iria conhecer dias melhores de progresso científico após a nomeação do Prof. Juliano Moreira, em 1902, pelo Ministro J. J. Seabra, ambos baianos, no governo do Presidente Rodrigues Alves. Essa inauguração iria repercutir nas grandes províncias do Império, fazendo com que seus presidentes assumissem a missão de edificar hospícios para alienados.

Em São Paulo, em 1852, é criado o Asilo Provisório do Largo dos Curros (atual Praça da República), depois transferido para a Ladeira da Tabatinguera, na Várzea do Carmo. O Hospício do Juqueri só seria concluído em 1903. Em Pernambuco, os doentes do Hospital de São Pedro de Alcântara, no Convento do Carmo, em Recife, foram transferidos para o Hospício da Visitação de Santa Isabel, em Olinda, no ano de 1860. Entre 1874 e 1883, foi construído pelo Barão de Lucena, no sítio da Tamarineira, o Hospício de Alienados, por meio de subscrições populares, quermesses e recursos públicos. Foi na Tamarineira que o antigo discípulo de Juliano Moreira, Ulysses Pernambucano de Mello, nos anos 20 e 30 do século XX, revolucionaria a assistência psiquiátrica brasileira, por meio de inovações pioneiras 
no país e na América Latina. Em 1873, começou a funcionar o Asilo de Alienados do Pará, bem próximo ao leprosário, em Tucunduba; depois, os pacientes foram enviados para o Hospício de Alienados, no Marco da Légua. Na Bahia, os alienados foram transferidos, em 1874, do Hospital de São Cristóvão para o Asilo de São João de Deus, instalado em uma bela chácara, que receberia posteriormente o nome de Hospital Juliano Moreira. O Hospício São Pedro, no Rio Grande do Sul, conhecido na época como o "Cadeião", foi construído em 1884 e depois administrado e mantido pelo poder público.

Outras províncias seguiram o exemplo: em Fortaleza, Asilo de Alienados de São Vicente de Paula, em Porangaba (1886); em Maceió, Asilo Santa Leopoldina (1891); na Paraíba, Asilo do Hospital Santa Ana, em Cruz do Peixe (1893); em Manaus, Hospício Eduardo Ribeiro (1894); em Barbacena (MG), Hospital Colônia (1903); e assim por diante.

No início, os alienistas praticavam uma neuropsiquiatria, de inspiração nitidamente francesa, baseada nas obras de Pinel, Esquirol, Magnan, Chaslin, Babinski, Pitres e Régis, etc. Os regulamentos dos hospícios de alienados seguiam as orientações pinelianas: a busca da razão e a luta contra a "desrazão". Após Juliano Moreira assumir a direção do Hospício Nacional de Alienados, a influência germânica instalou-se no país. São conhecidos os trabalhos de Griesinger, Bonhoeffer, Birnbaum, Kraepelin, Lange e muitos outros.

Nuno Rodrigues foi o primeiro alienista a estagiar no exterior, e Teixeira Brandão, o primeiro professor de Psiquiatria a ser admitido por concurso público, em 1883, no Rio de Janeiro. O ensino oficial de psiquiatria no país começou quase simultaneamente no Rio de Janeiro (Nuno de Andrade, 1881; e Teixeira Brandão, 1883) e na Bahia (em 1886), com Demétrio Tourinho e Augusto Maia.

Já estamos no final do século XIX e início do século XX. Esses são os primeiros passos, os primórdios da assistência e do ensino da Psiquiatria no país.

\section{Bibliografia consultada}

1. Bastos O. História da psiquiatria em Pernambuco e outras histórias. São Paulo: Lemos; 2002.

2. Bastos O. The history of psychiatry and mental health in Brasil. In: Bastos O. História da psiquiatria em Pernambuco e outras histórias. São Paulo: Lemos; 2002.

3. Medeiros TA. Formação do modelo assistencial no Brasil [dissertação de mestrado]. Rio de Janeiro: Universidade Federal do Rio de Janeiro; 1977. 